\title{
悪性黒色腫に対する化学・ホルモン療法
}

\author{
瀬尾達・小笠原 寛・森 裕司 \\ 天野 吉晴*・伊達 和宏*·阪上 雅史
}

\section{Chemohormonal Therapy for Malignant Melanoma}

\author{
Wataru Seo, Hiroshi Ogasawara, Hiroshi Mori, and Masafumi Sakagami \\ (Hyogo College of Medicine)
Yoshiharu Amano and Kazuhiro Date
(Hyogo Prefectural Awaji Hospital)

\begin{abstract}
The prognosis of malignant melanoma is very poor especially when it originates in the head and neck region such as the nasal, paranasal sinus, and oral mucosa. Although surgical therapy, radiotherapy, chemotherapy, immunotherapy, interferon therapy, and other therapies have been suggested for treatment of this malignant disease, there are still no therapies established as definitely effective. We attempted various types of therapies for our patients with primary nasal or paranasal malignant melanoma with unsatisfactory results. However, chemotherapy using anti-estrogen TAM (Tamoxifen ${ }^{\circledR}$ ) has provided satisfactory results in 2 patients. The regimen of this chemohormonal therapy agreed with McClay's regimen. TAM is widely known as an anti-estrogen chemotherapeutic agent breast cancer and thought to exert anti-cancer effect by competing with estrogen for estrogen receptors in breast cancer tissues. The mechanism of the effect of TAM on malignant melanoma remains unknown. Although its anti-cancer mechanism must be further explored, we consider that this chemohormonal therapy will likely become very important in multidisciplinary therapy for malignant melanoma in the head and neck region.
\end{abstract}

Key words : malignant melanoma, TAM, estrogen receptor, chemohormonal therapy

はじめに

覀性黒色腫は極めて予後不良の疾患で, その内でも頭 頸部領域, 即ち鼻, 副鼻腔, 口腔等の粘膜に原発するも のは更に予後不良とされている，その治療法には手術療 法 $^{1)}$, 放射線療法 2 , , 化学療法3), 免疫療法4), インター フェロン療法5) 等があるが，有効な治療法は確定されて 扣らず，セーフティーマージンをとった広範囲な外科的 切除が最も確実とされている．ただし頭頸部領域では早 期発見が困難なため治療開始が遅れがちであるのに加兄 て，その解剖学的特性より前述のような健常組織を含め
た充分な根治手術が不可能なケースが多く6)，そのほか の治療を組み合わせた集学的治療を行っているのが現状 である7.

今回私たちは鼻, 副鼻腔原発覀性黒色腫に対し, ダカ ルバジン(以下 DTIC) とシスプラチン(以下 CDDP)を中 心とする化学療法で有効 (Partial Response) または進行 (Progressive Disease)の結果しか得られなかった症例が， 抗エストロゲン剂である TAM (Tamoxifen ${ }^{\circledR}$ )を併用す る化学ホルモン療法を行い良好な結果を得ることができ たので，報告する. 
症例

症例 1 .

患者: 55歳, 男性.

主訴：左眼瞼下垂, 複視.

現病歴：昭和 63 年頃より左鼻出血があり当科紹介され た。鼻腔内に腫瘍性病変を認生検のら光鼻腔悪性黒色 腫と診断し, 当科飞て DTIC, VBL (Vinblastin), CDDP を使った化学療法, デンケル手術, インターフェロン療 法を行った。 その後, 再発の度にレーザー手術や免疫療 法, 頸部リンパ節郭清を行っていた。外来で経過観察中 であったが，平成 5 年末頃に急激に眼瞼下垂をきたした。

既往歴：特記すべきことなし。

現症 : 左眼瞼は下垂し眼裂の狭小，全眼筋麻痺を認め， 全方向で複視を伴った(図 1 ). 前鼻鏡で両側鼻腔は黒色 の腫瘤で充満して特り, 易出血性であった。他にリンパ 節腫脹等は認めなかった。

入院時 $\mathrm{CT}$ (図 2 ): 前鼻鏡所見之同様に, 左鼻腔を中 心に一塊となった大きな腫瘍を思わせる破壊性の占拠性 病変が両側鼻腔内に充満していた，病変は眼窩を全体に 圧迫しているものの眼简内側板は保たれていた。

入院後経過：直ちに腫瘍減量術を行うも急激な腫瘍増 大があり，腫瘍の頭蓋圧迫によると考兄れる半昏睡状 態になったためホルモン剤を含めた化学療法(化学ホル モン療法)を新たに開始した。化学ホルモン療法のレジ メンはMcClay らの方法8 飞準じたが，彼らのレジメン にある BCNU (Carmustine) に代光私たちは MCNU (Ranimustine)を用いた(表 1)。化学ホルモン療法を始 め, 肉眼的に鼻腔腫瘍は徐々に縮小し, 約 5 日間で意識

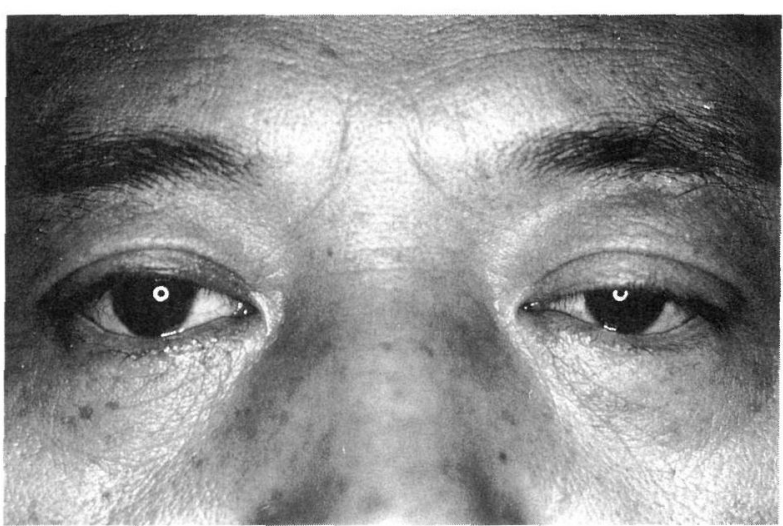

図 1 入院時所見 左眼裂下垂と眼裂の狭小を認めた。

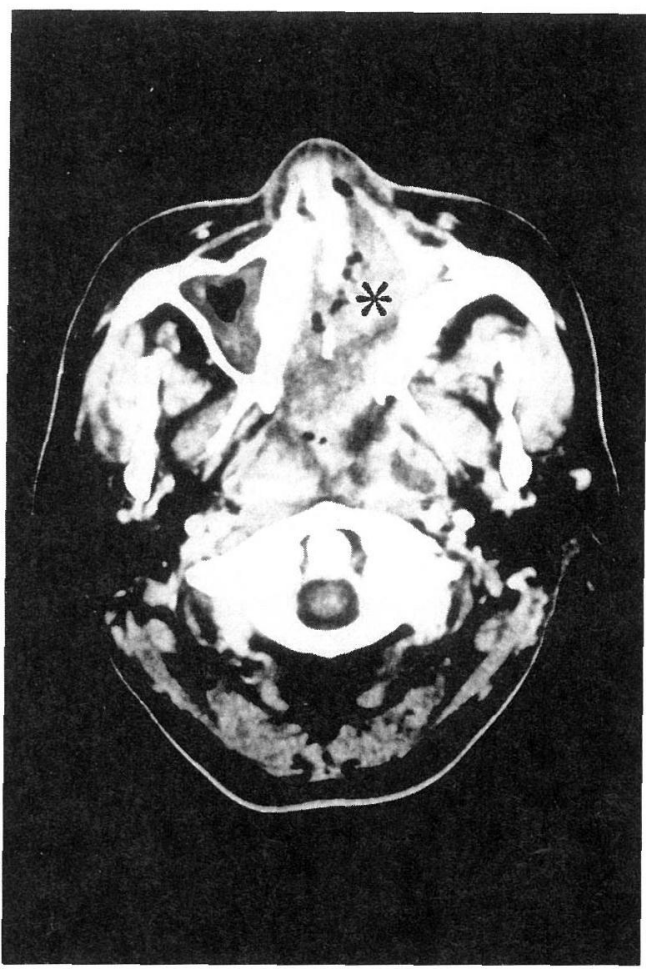

図 2 入院時 $\mathrm{CT}$

鼻腔内に充満する腫瘍陰影 (*)を認めた。

も徐々に回復し，治療は有效と考克られた．更に化学木 ルモン治療を始めた 2 力月後には腫瘍は肉眼的にほぼ消 失し, 眼筋麻瘦も回復した.

退院時の T1 強調 MRI 画像（図 3 ) 炎症性と思われ る粘膜肥厚を認める程度で腫瘍性病变の像を認めなかっ た.

退院後 6 カ月間の寬解期間を得たが，その後，肺炎の ため不幸な転帰をたどった。

症例 2 .

患者：59歳，女性.

表 1 化学ホルモン療法のレジメン

DTIC (Dacarbazine) $300 \mathrm{mg}$ daily 3 days

CDDP (Cisplatin) $30 \mathrm{mg}$ daily 3 days every 4 weeks

MCNU (Ranimustine) $200 \mathrm{mg}$ once every 8 weeks

TAM (Tamoxifen ${ }^{\circledR}$ ) $20 \mathrm{mg}$ twice daily permanently 


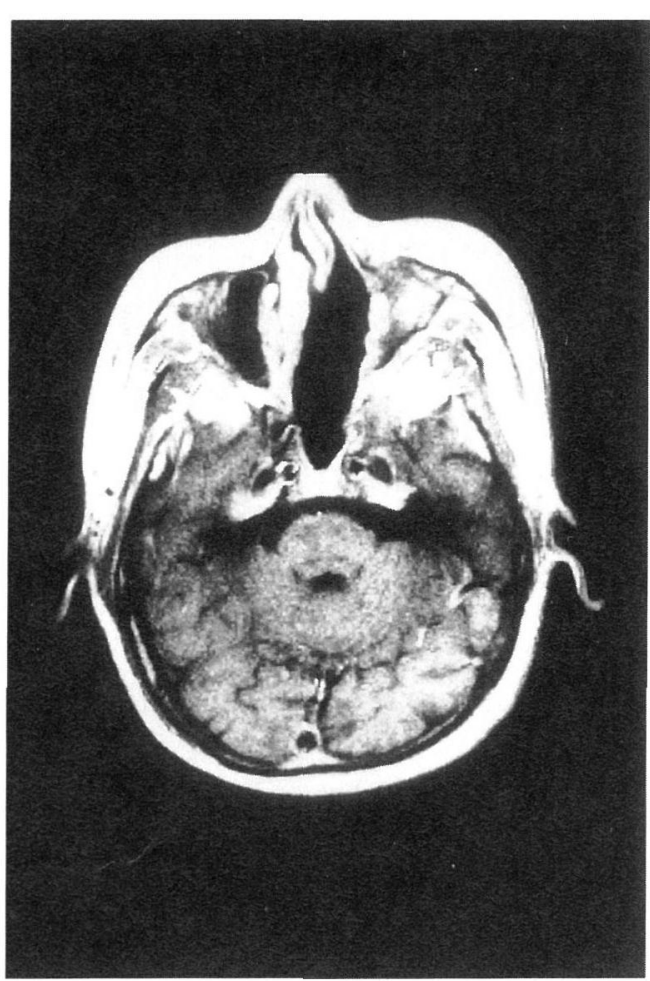

図 3 退院時 T1 強調 MRI 腫瘍陰影は消失した。

主訴：右鼻閉, 右鼻出血.

現病歴: 平成 5 年 1 月頃より右鼻閉, 右鼻出血が出現 し，近医より同年 6 月当科紹介された.

既往歴：高血圧，脳動脈瘤，C型肝炎.

現症 : 前鼻鏡で, 右中鼻道から総鼻道に暗赤色, 易出 血性の腫瘤を認めた。鼻出血と後鼻出血を伴っていた． 他に頸部扣よび全身にリンパ節を触知しなかった。

初診時の単純 CT 前額断(図 4): 右上顎洞の一部から 篩骨洞を破壞し鼻腔内に突出する占拠性病変を認めた。

生検の結果クロマチンを多く含有した比較的大型な核 と核小体を明瞭に有する腫瘍細胞のびをえ性増生が認め られ S100 蛋白陽性で悪性黑色腫の所見であった。

入院後経過：腫瘍の悪性度, 占拠範囲上り手術治療は 保留しDTICを中心とした化学療法を 2 コース, その 後 1 回大量間久照射を計 $60 \mathrm{~Gy}$ 行った.

化学療法, 放射線療法終了後の MRI 画像(図 5 ) : 上 顎洞に関しては腫瘍陰影は殆ど消失しているが，篩骨蜂 巣から鼻腔内の腫瘍は縮小しているものの残存し, $\mathrm{Gd}$ により不均一飞造影されていた。腫瘍の縮小性不完全で

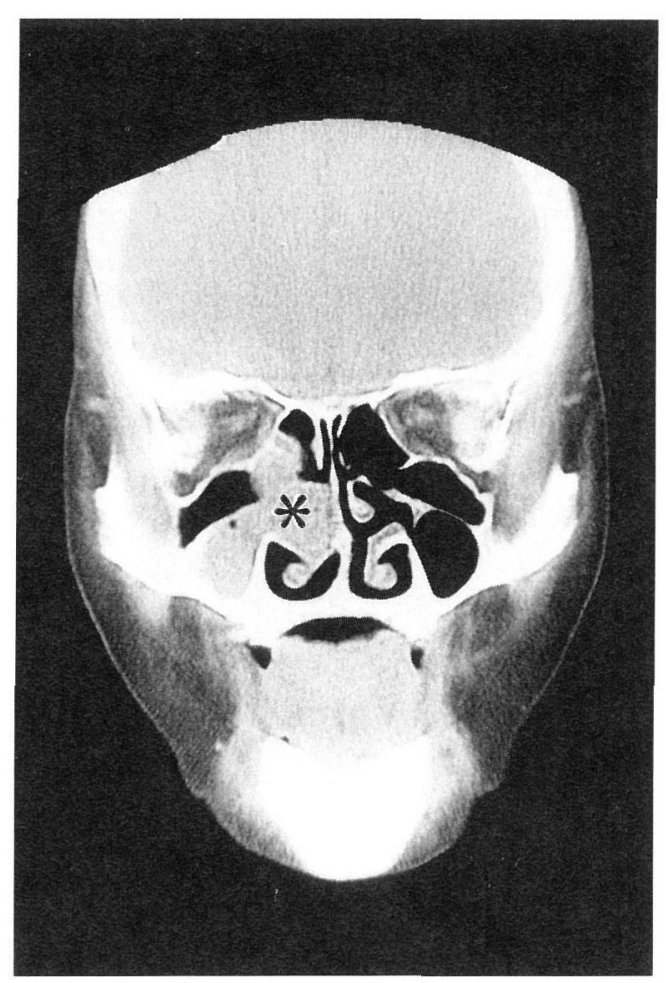

図 4 入院時 $\mathrm{CT}$ 前額断

右上㴿洞, 篩骨洞, 鼻腔に充満する腫瘍陰影 $(*)$ を認め た。

あったが, 肝機能が悪化したため治療を中断, 休止した。 約 2 カ月で肝機能が正常化し全身状態も良好となったた め, TAMをふくめた化学ホルモン療法に变更した、レ ジメンは症例 1 と同様とし, 化学ホルモン療法を開始す ると, 次第に肉眼的に腫瘍は縮小し, 約 2 力月で腫瘍は 消失し, 鼻閉, 鼻出血も消失した。气の間, 一過性の血 小板減少症を認めたが，その後回復した.

化学ホルモン療法施行後の T1 強調 MRI 画像(図 6 ) 前部篩骨蜂栄の一部に僅かに高信号領域を認める程度で 腫瘍の縮小傾向は明らかであった。

その後, 約 5 カ月間の寛解を経て, 現在も観察中であ る。

\section{考察}

悪性黒色腫は速やかな経過を呈し極めて予後不良の転 帰をとることが多い，原発巣の制御が治療の基本ではあ るものの9), それは容易なことではない。治療法として は, 所属リン八節の転移巣が形成されるまでの早期の段 


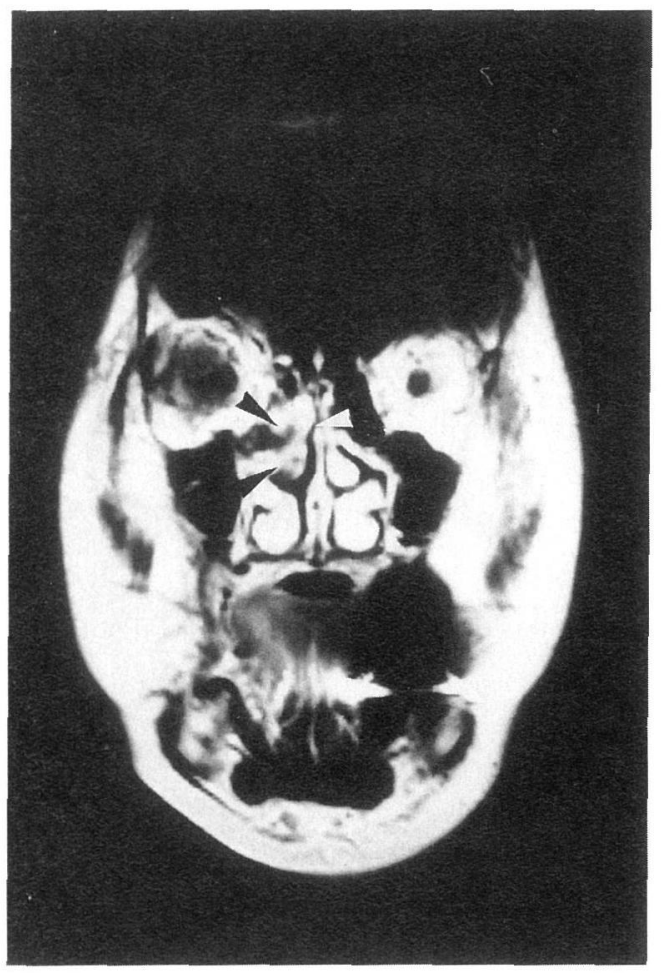

図 5 DAV 療法, 放射線療法後の MRI 腫瘍の縮小は不完全であり，残存(矢印で囲まれた部位) していた。

階での原発单の完全な外科的切除が理想的である. 切除 範囲は原発巣周囲に多発する小結節(黒色斑)のために セーフテイーマージンは約 $50 \mathrm{~mm}$ 程度は必要とされて いる。しかし，実際には頭頸部領域においては手術療法 は不可能な場合が多く，様々な治療法が試行錯䛊されて いるが, 現在では化学療法が手術療法に次いで重要な治 療法とされている。化学療法について本邦では DTIC を中心としたいわゆるDAV (DTIC, ACNU, Vincristine) 療法やPAV (Peplomycin, ACNU, Vincristine) 療 法が多く行われ，CDDPも用いられる。また，最近で は，免疫療法も試行されつつある。

私たらも悪性黒色腫に対し, 手術治療, 化学治療, 放 射線治療，免疫療法など最初様々な治療を行ったにもか かわらず，満足すべき結果を得ることができず，僅か 2 例ではあるが，TAMを併用したDTIC， CDDP， MCNUの 4 者の化学ホルモン療法を行い McClay $5^{8)}$ の報告を支持する良好な結果を得ることができた。

McClay ${ }^{8)}$ は1992年, 65例の悪性黒色腫(内, 粘膜部

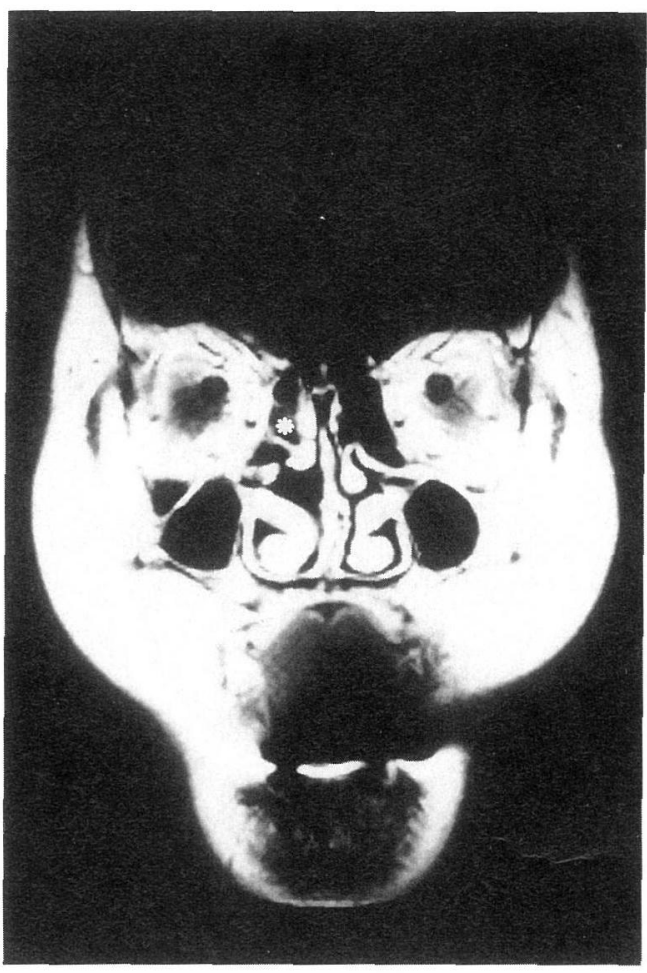

図 6 化学ホルモン療法後の MRI 腫瘍はほ涪消失 $(*)$ していた。

位38例)に対しDel Prete ら ${ }^{10)}$ の原法に準じ化学ホルモ ン療法を行いTAMを併用した場合と TAM を併用し なかった場合とを比較し評価を加光ている。そのなかで， 彼らはTAMを併用した45例のらち18例(40\%)に効果 を認め, TAM を併用しなかった場合20例のらら 2 例 $(10 \%)$ に比べ格段に有効であり, 平均生存期間の向上を 得ることができた，と報告している．副作用として彼ら は必発する吐気, 嘔吐の他, 血小板減少症を中心とする 沉血球減少症走あげているが，私たちの症例でも昍気， 嘔吐の他には一過性の軽度血小板減少症を認めた程度で あり，特に問題となるものはなかった(表 2 ).

TAM は乳癌の治療薬として一般に知られて扣り乳癌 組織のエストロゲンレセプターに対しエストロゲンに競 合的に結合し抗エストロゲン作用を示すことによって抗 癌作用を発揮すると考光られているものの, 悪性黒色腫 に対する TAMの作用の機序に関しては明らかではな W.

Nesbit ら ${ }^{11)}$ は1979年進行性の悪性黒色腫に対して初 めて単剤として TAM を投与し，約 $30 \%$ 程度の症例に 
表 2 化学ホルモン療法の副作用8)

\begin{tabular}{c|c}
\hline \hline & 割合 $(\%)$ \\
\hline 好中球减少 & 20 \\
\hline 貧 血 & 44 \\
\hline 血小板减少 & 48 \\
\hline 腎障害 & 8 \\
\hline 低マグネシウム血 & 32 \\
\hline 悪心/嘔吐 & 100
\end{tabular}

反応が認められ，なかでも軟部組織では特に良好であっ たと報告したそそしてその作用機序は不明なものの，エ ストロゲンレセプターに直接作用することよりも，むし ろ間接的な効果によるものであろう，と推測している. その後, Masiel ら ${ }^{12)}$, Reimer $5^{13)}$, Creagan $5^{14)}$, Meyskens ら ${ }^{15)}$ はTAM を単剤で悪性黒色腫に対して使用し 有効である，と評価を加えている.

一方で Mirimanoff ら ${ }^{16)}$ は再発性の悪性黒色腫に対し てTAMを投与し長期間にわたり奏功 (Complete Response) を得た症例を報告し，悪性黒色腫のホルモン 依存性につき示唆して扣り，さらに，Fisher ら ${ }^{17)}$ は悪 性黒色腫の約 $46 \%$ にエストロゲンレセプターの存在を確 認したが，エストロゲンレセプターの存在の有無が必ず しも悪性黒色腫に対する TAM の有効性を左右しな (18)19)，という報告もあり，実際に私たちの症例でも， 症例 1 でエストロゲンレセプターの存在を確認したが陰 性であった(症例 2 については同定していない).

いずれにせよ，最近の報告で Rumke ら ${ }^{20)}$ はそれらの 点も含め, TAM の単剂使用では悪性黒色腫の治療効果 に限界がある，と結論づけている。

TAM の有効性について, Del Prete ら ${ }^{10)}$ は TAM は 単剂で用いるよりも CDDP と併用することではるかに 有用であると報告し，McClay 58) 対して増感作用をもつために，悪性黒色腫の治療に有効 であると主張している。そして，彼らの最近の報告21) では悪性黒色腫に対してだけではなく肺小細胞癌, 卵巣 癌等に扣いても TAM と CDDP は相互に増感作用があ り，治療に有効である，と述べている。それとは別に彼 らは，CDDP に抵抗する悪性黒色腫でも TAMを加え ることで効果を認めた症例22，を報告している.

$\mathrm{TAM}$ と CDDP との相互作用については種々の基礎
的実験による説明が試みられている．Hofmann ら ${ }^{23)}$ は ラットを用いて，腫瘍細胞に TAM と CDDP とを投与 することで腫瘍の増殖を抑制することを明らかにした。 その際，TAM は C 蛋白キナーゼ阻害剤として働き，C 蛋白キナーゼの細胞膜に作用し細胞増殖に必要な酵素の 転換過程を阻害するものと述べている.

最近の McClay ら ${ }^{24)}$ の報告では，様々なレジメンの 化学療法だけでなく, 免疫療法, またそれらの集学的療 法も含めた治療法に評価を加えて扣り，なかでも化学木 ルモン療法がいかなる評価基準でも最も有効であった， と報告している.

本邦では悪性黒色腫に対する化学ホルモン療法の治療 経験は報告されていないが，今回，私たちも，その有効 性を支持する結果を得ることができた．今後，その有効 性のメカニズムの究明が必要だが，化学ホルモン療法が 頭頸部領域の悪性黒色腫の集学的治療に非常に重要な役 割を占める可能性があると考える。

\section{まとめ}

さまざまな治療に抵抗した鼻, 副鼻腔原発の悪性黒色 腫に本邦ではじめて抗エストロゲン剤である TAMを 含む化学ホルモン療法を行い極めて良好な結果を得たの で報告した。

本論文の要旨の一部は第18回日本頭頸部腫瘍学会(1994年 6 月23日，札幌市)で発表した。

\section{参考文献}

1) Shah JP, Huvos AG and Strong EW : Mucosal melanomas of the head and neck. Am J Surg $134: 531 \sim 535,1977$.

2 ) Holdcraft J and Callagher JC : Malignant melanomas of the nasal and paranasal sinus mucosal. Ann Otol Rhino Laryngol 78 : 5 20, 1969.

3 ) Bellet RE : Chemotherapy of malignant melanoma. Cancer Chemotherapy $3: 225 \sim 237,1978$.

4) West WH, Taurer KW, Yannelli JR, et al : Constant infusion of recombinant interleukin- 2 in adoptive immunotherapy of advanced cancer. N Engl J Med $316: 898$ $\sim 905,1987$.

5 ) Rosenberg SA, Lotze MT, Muul Lm, et al : Observations on the systematic administration of autologus lymphokine activated killer cells and interleukin-2 alone. N Engl J Med 316 : 889 905, 1987.

6 ) Eneroth CM and Lundberg C : Mucosal malignant mela- 
nomas of the head and neck. Acta Otolaryngol (Stockh) $80: 452 \sim 458,1975$.

7 ) 酒井俊一, 伊藤真人, 兵 行和, 他 : 頭頸部粘膜に発生し た悪性黒色腫30例. 耳鼻臨床 $78: 2799 \sim 2818,1985$.

8 ) McClay EF, Masarangelo MJ, Bread D, et al : Effective combination chemohormonal therapy for malignant melanoma. Int J Cancer : $50: 553 \sim 556,1992$.

9 ) Lee SP, Shimizu KT, Tran LM, et al : Mucosal melanoma of the head and neck; the impact of local control on survival. Laryngoscope $104: 121 \sim 126,1994$.

10) Del Prete SA, Maurer LH, O’Donnell, et al : Combination chemotherapy with cisplatin, carmustine, dacarbazine and tamoxifen in metastatic melanoma. Cancer Treat Rev $68:$ 1403 1405, 1984.

11) Nesbit RA, Woods RL, Tatrersall $\mathrm{MH}$, et al : Tamoxifen in malignant melanoma. N Eng J Med 301 : 1241, 1979.

12) Masiel A, Buttrick $P$ and Bitran J : Tamoxifen in the treatment of malignant melanoma. Cancer Treat Rev $65: 531$ $\sim 532,1981$.

13) Reimer RR, Costanzi J and Fabian C : Southwest oncology group experience with tamoxifen in metastatic melanoma. Cancer Treat Rev $66: 1680 \sim 1681,1982$.

14) Creagan ET, Ingl JN, Green SJ, et al : Phase II study of tamoxifen in patients with dissenminated melanoma. Cancer Treat Rev 64 : 166 201, 1980.

15) Meyskens FJ Jr and Voakes JB : Tamoxifen in metastatic malignant melanoma. Cancer Treat Rev $64: 171 \sim 173$, 1980.

16) Mirimanoff RO, Wagenknecht L and Hunziker : Long $\mathrm{N}$ term complete remission of malignant melanoma with Tamoxifen. Lancet $1: 1368 \sim 1369,1981$.

17) Fisher RI, Nelfeld JP and Lippmann ME : Estrogen receptors in human malignant melanoma. Lancet $2: 337 \sim 338$,
1976.

18) Papac R, Luikhart S and Kirkwood J : High dose tamoxifen in patients with advanced renal cell cancer and malignant melanoma. Proc Am Assoc Cancer Res/ASCO 21 : 345, 1980.

19) Fisher RI, Young RC and Lippmann ME : Diethylstibestrol therapy of surgically non resectable malignant melanoma. Proc Am Asoc Cancer Res/ASCO $19: 339$, 1981.

20) Rumke P, Kleeberg UR, Maokie RM, et al : Tamoxifen as a single agent for advanced melanoma in post menopausal women; a phase II study of the EORTC malignant melanoma cooperative group. Melanoma Res 2 : 153 155, 1992.

21) McClay EF, Christian R, Albright KA, et al : Tamoxifen modulation of cisplatin cytotoxity in human malignancies. Int J Cancer 55 : 1018 1022, 1993.

22) McClay EF, Albright KA, Jones Ja, et al : Tamoxifen modulation of cisplatin resistance in patients with metastatic melanoma; a biologically important observation. Cancer $72: 1914 \sim 1918,1993$.

23) Hofmann J, Doppler W, Jakob A, et al : Enhancement of the anti proriferative of CDDP and nitrogen mustard by inhibitors of protein kinase C. Int J Cancer $42: 382 \sim 388$, 1988.

24) McClay EF and McClay ME : Tamoxifen; is it useful in the treatment of patients with metastatic melanoma? J Clin Oncol 3 : 617 626, 1994.

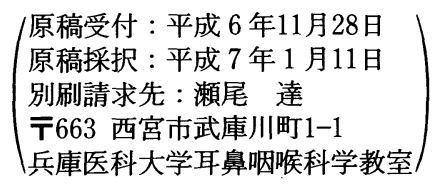

